\begin{tabular}{lccc} 
& GOSPODARKA & SUROWCAMI & MINERALNYMI \\
\hline Tom 28 & 2012 & Zeszyt 3 \\
& \multicolumn{2}{c}{ DOI 10.2478/v10269-012-0019-x }
\end{tabular}

\title{
Fazy mineralne w triasowych skalach węglanowych rejonu Chorzowa
}

\begin{abstract}
Wprowadzenie
W obszarze Górnego Śląska występuje fragment profilu utworów triasowych, od pstrego piaskowca do kajpru. Są to osady epikontynentalnego Zbiornika Germańskiego (Bodzioch 1990, 1998; Stanienda 2008, 2011; Szulc 1990, 2000). Przedmiotem niniejszego artykułu sa wapienie, występujące w niektórych obszarach rejonu Chorzowa. Spotyka się tu skały utworów węglanowych stropowej części profilu pstrego piaskowca oraz osady spagowej części profilu utworów wapienia muszlowego - warstw gogolińskich.

W północnej części Chorzowa (rejon Maciejkowic, częściowo Chorzowa Starego) występują skały wieku triasowego. Są one reprezentowane przez wapienie, dolomity i margle, a także piaski i iły pstrego piaskowca oraz wapienie, margle i dolomity wapienia muszlowego (rys. 1). Utwory te na obszarze Chorzowa przykryte są czwartorzędowymi osadami lodowcowymi (gliny, piaski), a także iłami i piaskami trzeciorzędowymi. Miąższość nadkładu nad skałami triasowymi dochodzi do kilku metrów.

W XIX wieku i pierwszej połowie XX skały weglanowe były na obszarze Chorzowa eksploatowane na potrzeby działającej w tym mieście huty (Königshütte, później Kościuszko) oraz budownictwa (rys. 2) (Encyklopedia Chorzowa 2009; Nowak 2007; Ziemia 1928). Niestety, dostęp do dawnych kamieniołomów został odcięty poprzez zasypanie ich

* Dr inż., Instytut Geologii Stosowanej, Wydział Górnictwa i Geologii, Politechnika Śląska, Gliwice; e-mail: katarzyna.stanienda@polsl.pl,jacek.nowak@polsl.pl

** Mgr inż., Katedra Nauki o Materiałach, Wydział Inżynierii Materiałowej i Metalurgii, Politechnika Śląska, Katowice; e-mail: tomasz.kukielka@polsl.pl
\end{abstract}




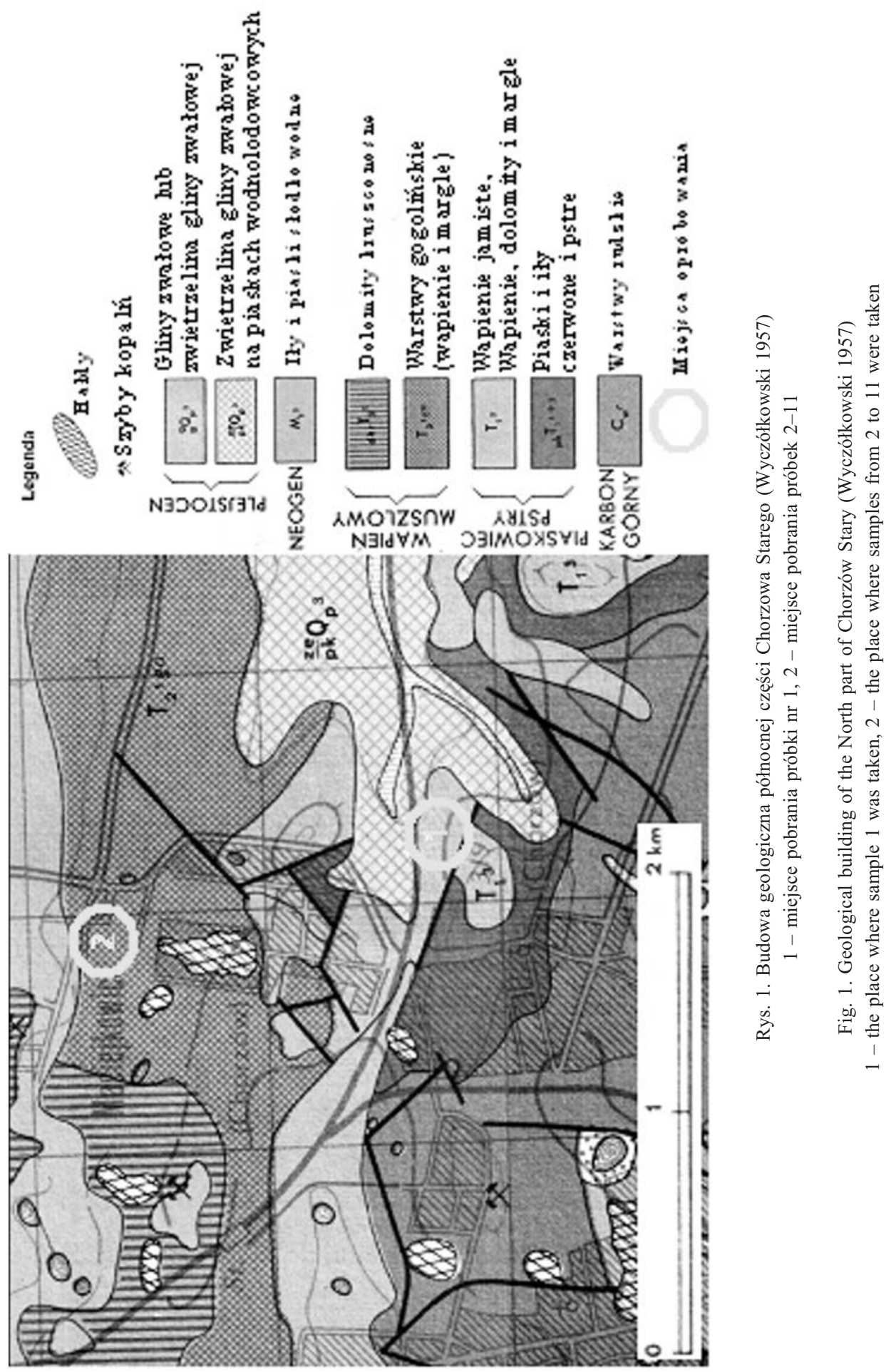




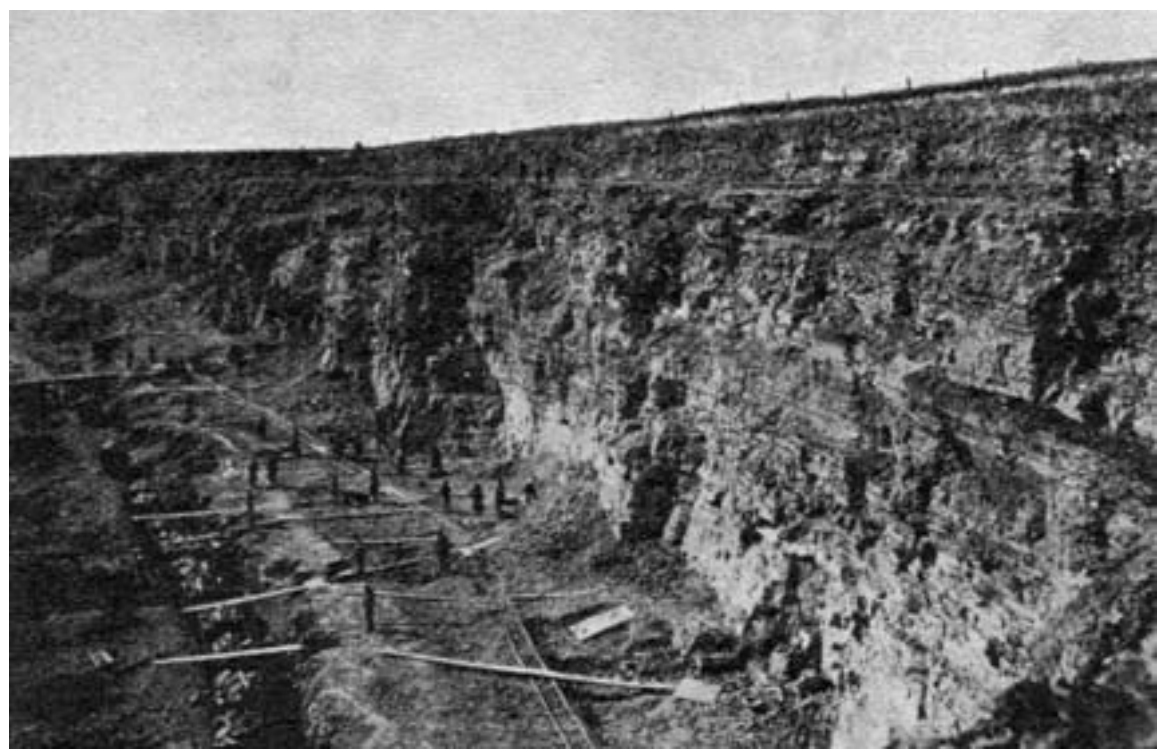

Rys. 2. Kamieniołom wapienia w Maciejkowicach w czasie około 1928 roku. Fot. M. Steckel (Ziemia 1928)

Fig. 2. Quarry of limestone in Maciejkowice in the time of the year 1928. Photo M. Steckel (Ziemia 1928)

odpadami górniczymi, wysypiskami śmieci, a także częściowe zasypanie i za- budowanie obiektami przemysłowymi. Obecnie na terenie Chorzowa nie ma dostępnych wychodni skał węglanowych.

Jednak prowadzone w ostatnich latach na terenie północnej części Chorzowa prace ziemne (przebudowa kanalizacji, fundamentowanie budynków) pozwoliły na pobranie próbek, które poddano badaniom (rys. 1). W trakcie pobierania próbek kierowano się makroskopowym zróżnicowaniem skał, a także lokalizacją prac ziemnych (rys. 3, 4).

\section{Metodyka badań}

Podczas prac terenowych wykonano dokumentację fotograficzną miejsc pobrania próbek skał oraz pobrano, z poszczególnych wydzieleń, reprezentatywne dla nich próbki punktowe do badań laboratoryjnych. Próbki skał węglanowych opisano makroskopowo, a następnie poddano je badaniom mikroskopowym $\mathrm{w}$ świetle przechodzacym, analizie rentgenograficznej oraz badaniom przy zastosowaniu elektronowego mikroskopu skaningowego. Opis mikroskopowy w świetle przechodzącym wykonano przy użyciu mikroskopu polaryzacyjnego AXIOSKOP firmy ZEISS, wyposażonego w analizator obrazu KS 300. Analizę rentgenograficzną wykonano przy użyciu dyfraktometru HZG4 przy zastosowaniu lampy miedziowej z filtrem niklowym, warunki analizy: napięcie $35 \mathrm{kV}$, natężenie $18 \mathrm{~mA}$. Elektronową mikroskopię skaningową przeprowadzono przy użyciu mikroskopu z zimną katodą (FEG) Hitachi S-4200, wyposażonego w detektor promieniowania rentgenowskiego z dys- 


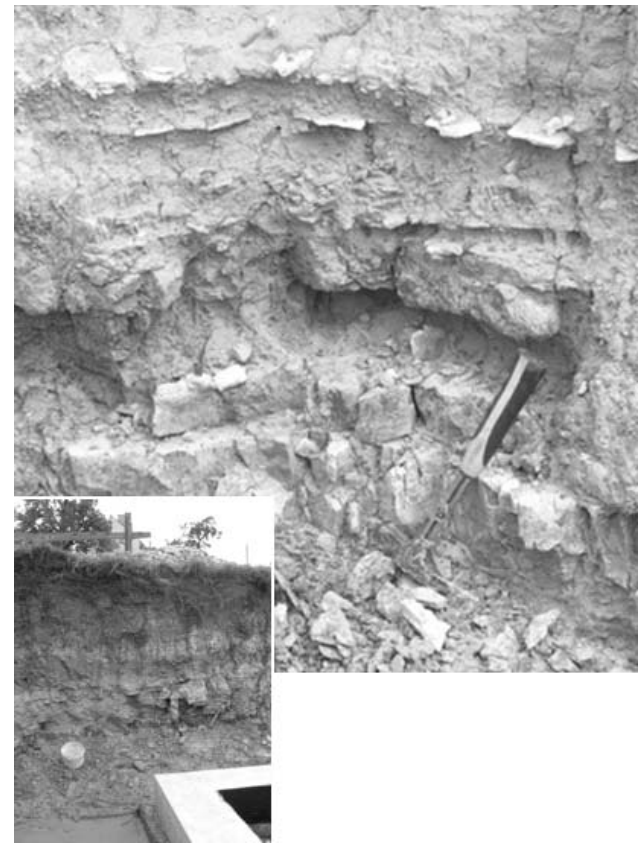

Rys. 3. Utwory pstrego piaskowca w wykopie fundamentowym w Chorzowie Starym Fig. 3. Sediments of Bundsandstain from the foundation excavation in Old Chorzów

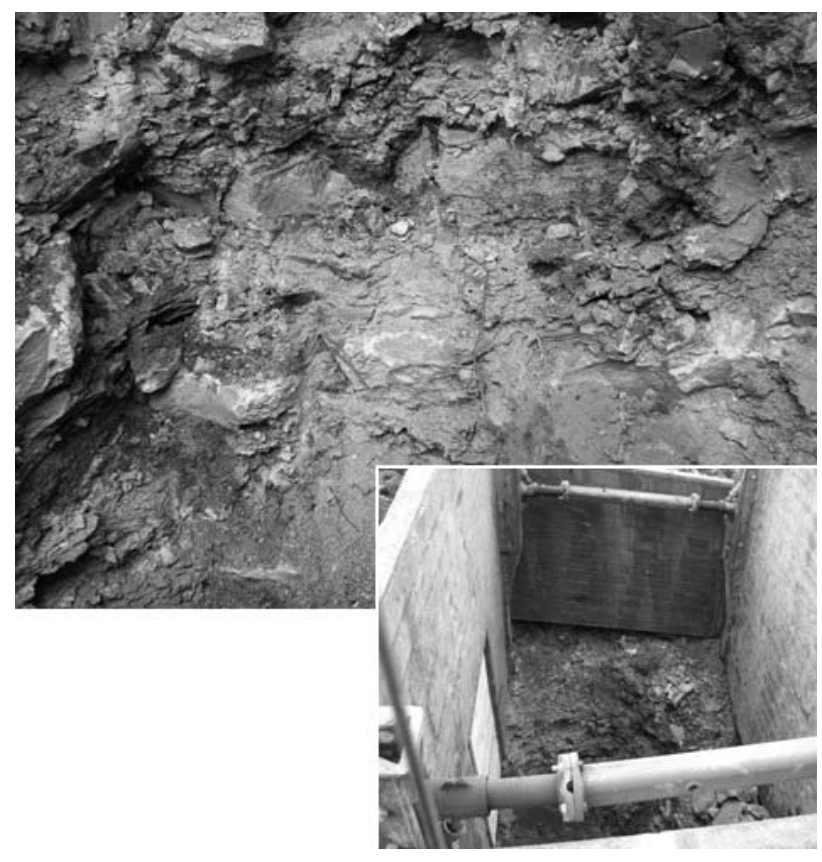

Rys. 4. Utwory wapienia muszlowego w wykopie w Maciejkowicach

Fig. 4. Sediments of Bundsandstain from the excavation in Maciejkowice 
persją energii (EDS) firmy THERMO. Obserwacje próbek prowadzono stosując technikę elektronów wtórnych (SE) przy napięciu przyspieszającym 15,0 kV. Uzyskane wyniki pomiarów analizowano z wykorzystaniem programu NSS (Noran System Seven). Przed przystąpieniem do analiz próbki zostały napylone grafitem.

\section{Wyniki badań}

\subsection{Charakterystyka petrograficzna badanych skał}

Wapienie dolomityczne stropowej części profilu pstrego piaskowca to skały barwy żółtawej, wykazujące makroskopowo strukturę mikrytową oraz teksturę zbitą, bezładną (rys. 5). Są to skały o małej zwięzłości. Słabo reagują na zimno z HCl, silnie po sproszkowaniu, co wskazuje na obecność w tych skałach dolomitu.

W obrazach mikroskopowych badana próbka, pobrana z tych utworów (pr. 1), to skała o strukturze sparytowej i teksturze zbitej, bezładnej (rys. 6, 7). Skała zbudowana jest z podstawowej masy sparytowej, o zróżnicowanej wielkości kryształów. W masie tej dominują romboedryczne kryształy dolomitu, zidentyfikowano też kryształy kalcytu (rys. 6). Ponadto w skale występują, w postaci rozproszonej, domieszki związków żelaza, tworzące w niektórych obszarach skały agregaty (rys. 8). Wyniki analiz makroskopowej oraz mikroskopowej wskazują, że badana skała to dolomit.

Utwory triasu środkowego (wapienia muszlowego) rejonu Chorzowa, to skały warstw gogolińskich. Wykazują barwy od szarej (pr. 5) poprzez beżową (pr. 2, 3, 4, 6, 8, 9), ciemnobeżową (pr. 7) do brunatno-beżowej (pr. 10,11), strukturę najczęściej organodetrytyczną (pr. 3, 4, 8, 10), biomorficzną (pr. 9, 11) lub mikrytową (pr. 2, 6, 7). W wapieniach o strukturze mikrytowej (pr. 7) stwierdzono obecność gniazd wtórnego kalcytu (rys. 9). Jedna z próbek (pr. 5) posiada strukturę makroskopowo-psefitową (rys. 10). W skale występują okruchy skał węglanowych spojone cementem węglanowym.

W obrazach mikroskopowych badane skały wykazują struktury od biomorficznej (pr. 8, 9, 10) poprzez organodetrytyczną (pr. 3, 4, 5 i 11), sparytową (pr. 7), mikrosparytową (pr. 6) do mikrytowej (pr. 2). W skałach występują różnego typu bioklasty, najczęściej fragmenty muszli, trochity liliowców, fragmenty szkieletów, w mniejszym stopniu peloidy (rys. 11, 12). Bioklasty spojone są cementem najczęściej porowym, kontaktowym, miejscami palisadowym. W wapieniach, w składzie mineralnym dominują: kalcyt (rys. 11, 12, 13, 14, 15, 16, 17, 18), dolomit (rys. 11), w formie domieszek występują: kwarc (rys. 10), chalcedon i muskowit (rys. 12). Kalcyt buduje bioklasty oraz cement w wapieniach. Kryształy cementu są zróżnicowane pod względem wielkości (od mikrytu do sparytu) i kształtu. Prawdopodobnie pierwotna masa skał uległa rekrystalizacji oraz agradacji, co doprowadziło do powstania cementu drugiej generacji (rys. 9, 10, 11, 14). W skałach często można zaobserwować gniazda lub żyłki, zbudowane z większych ziaren kalcytu. W niektórych kryształach widoczna jest romboedryczna łupliwość (rys. 13). Dolomit występuje w obrębie 

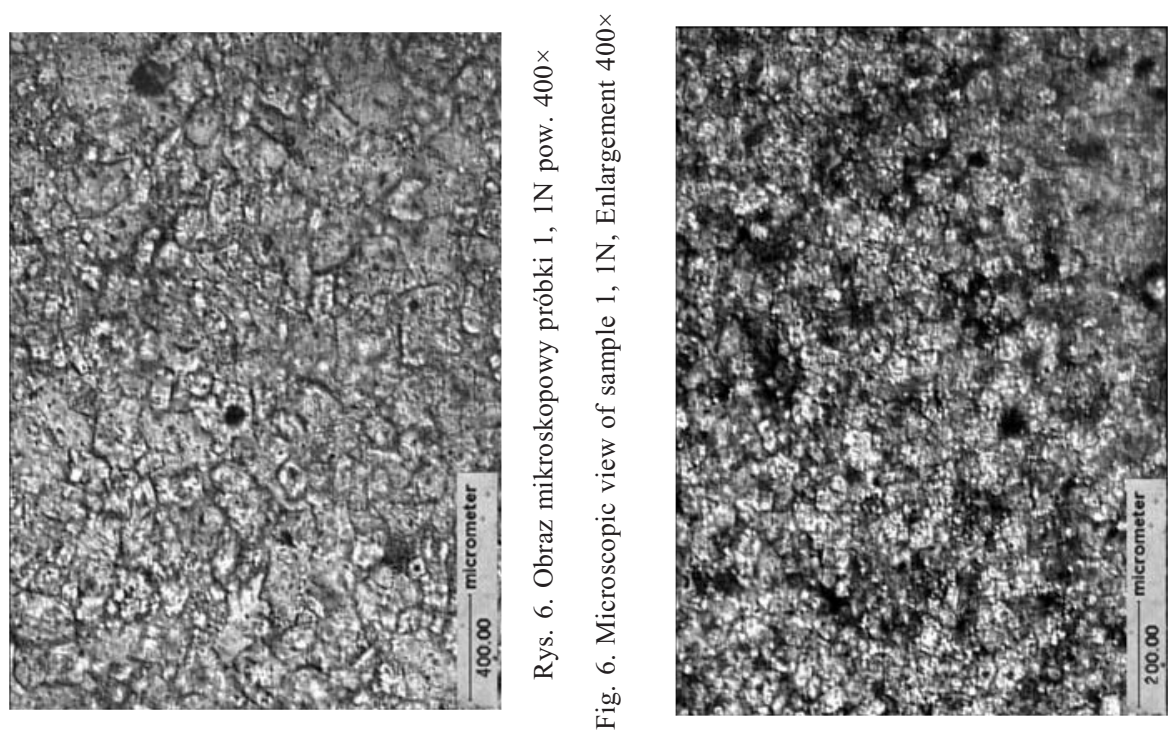

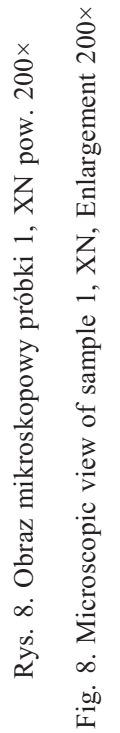
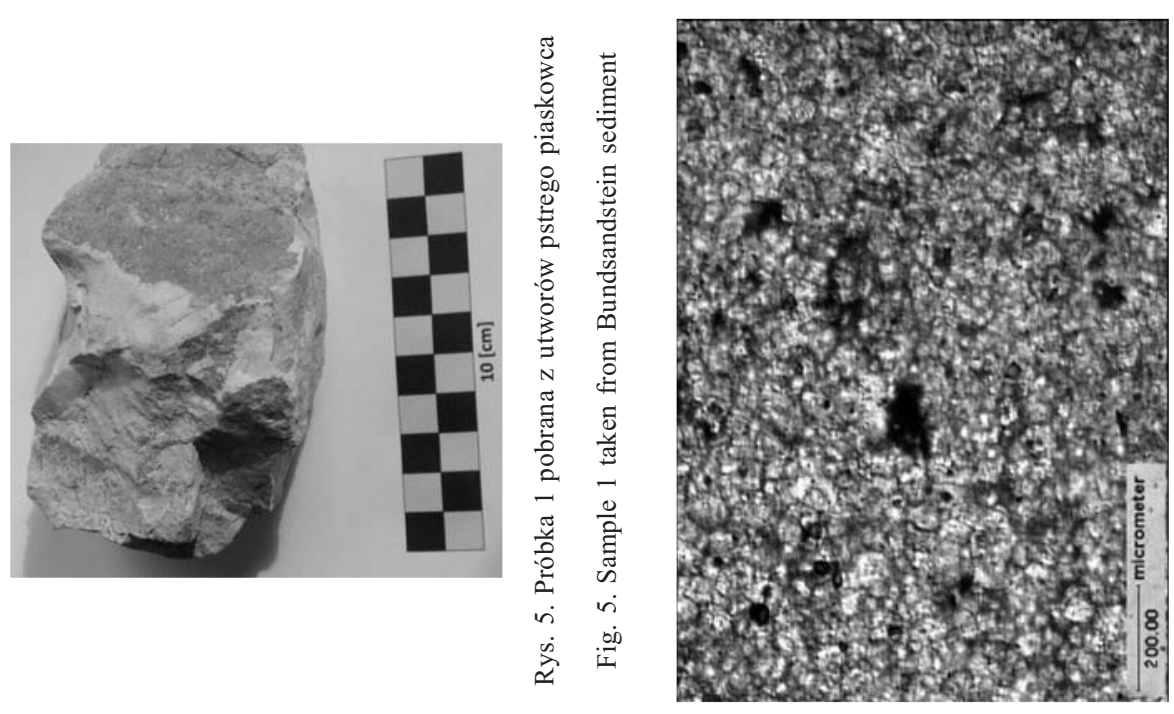

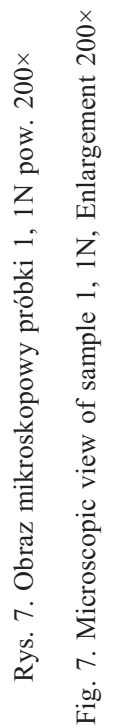



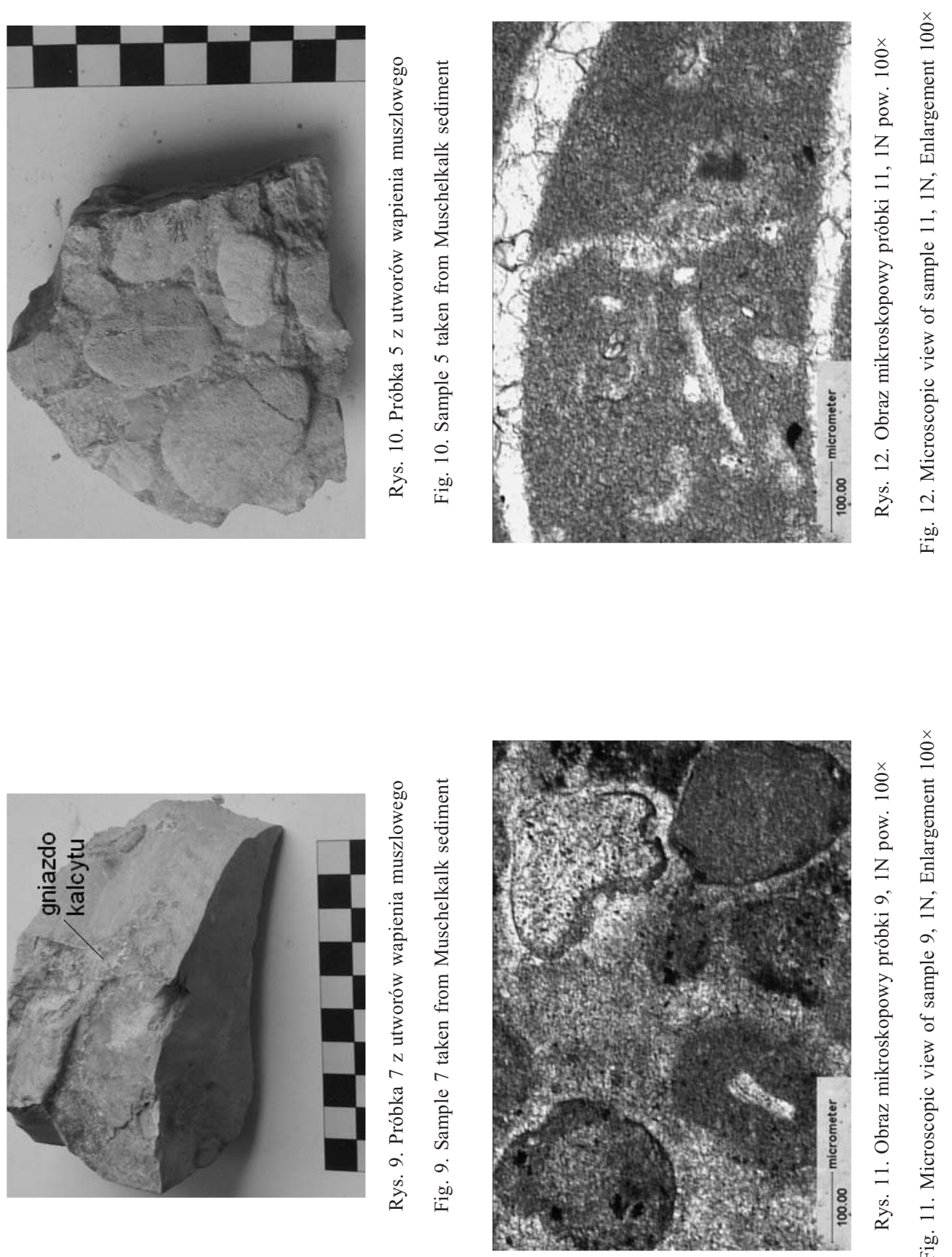

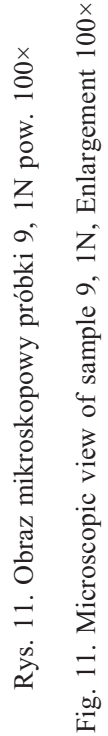



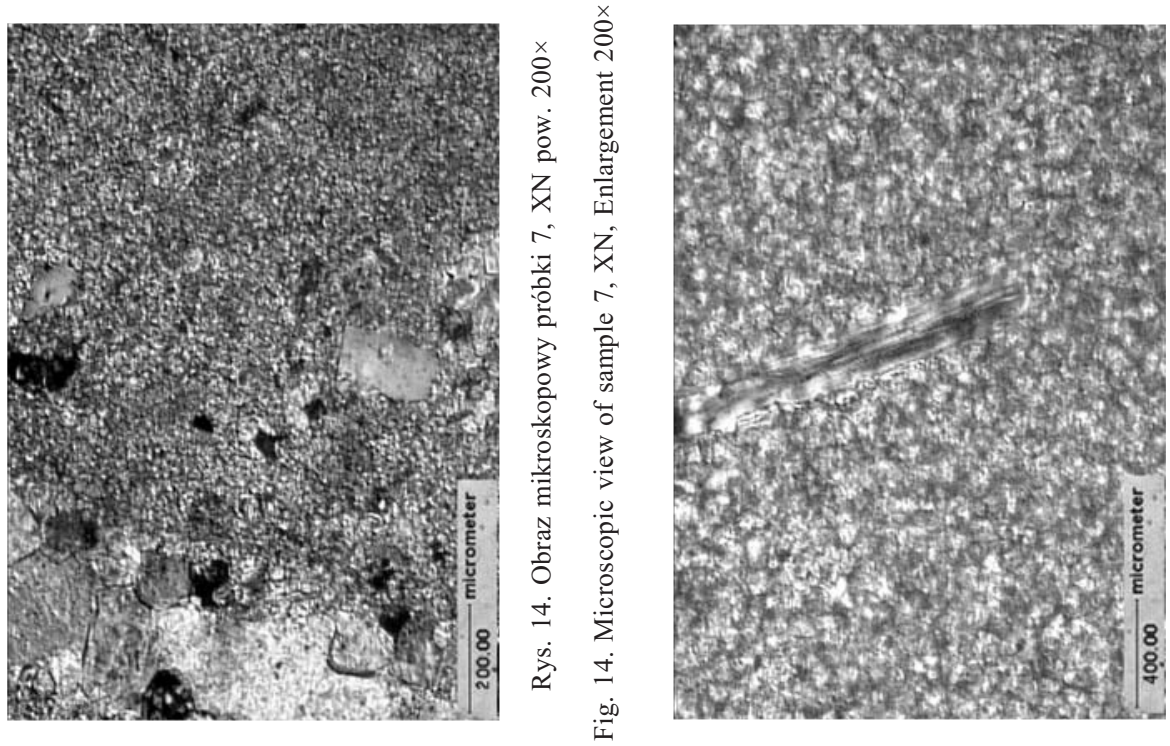

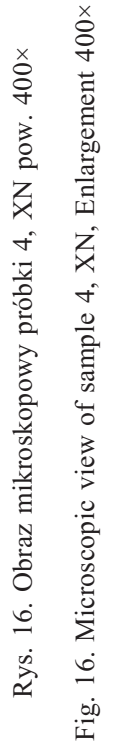
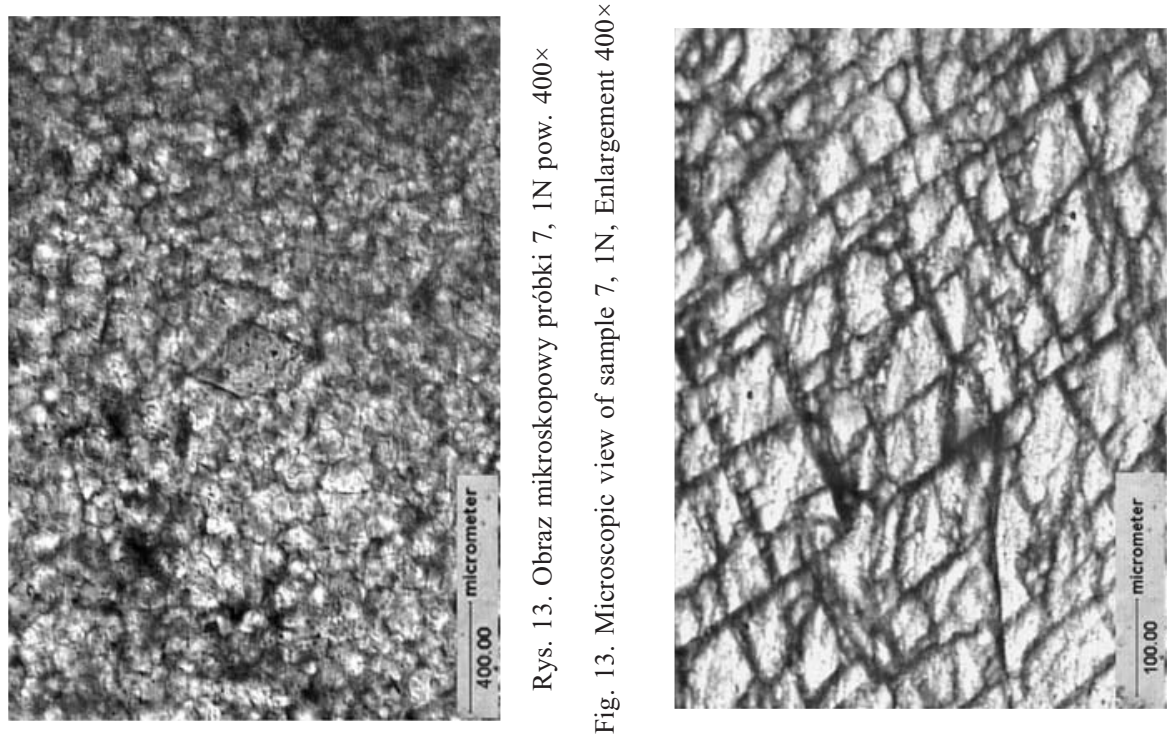

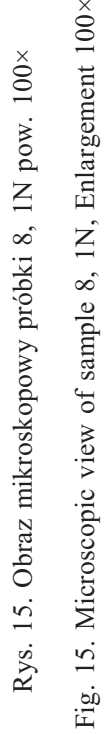



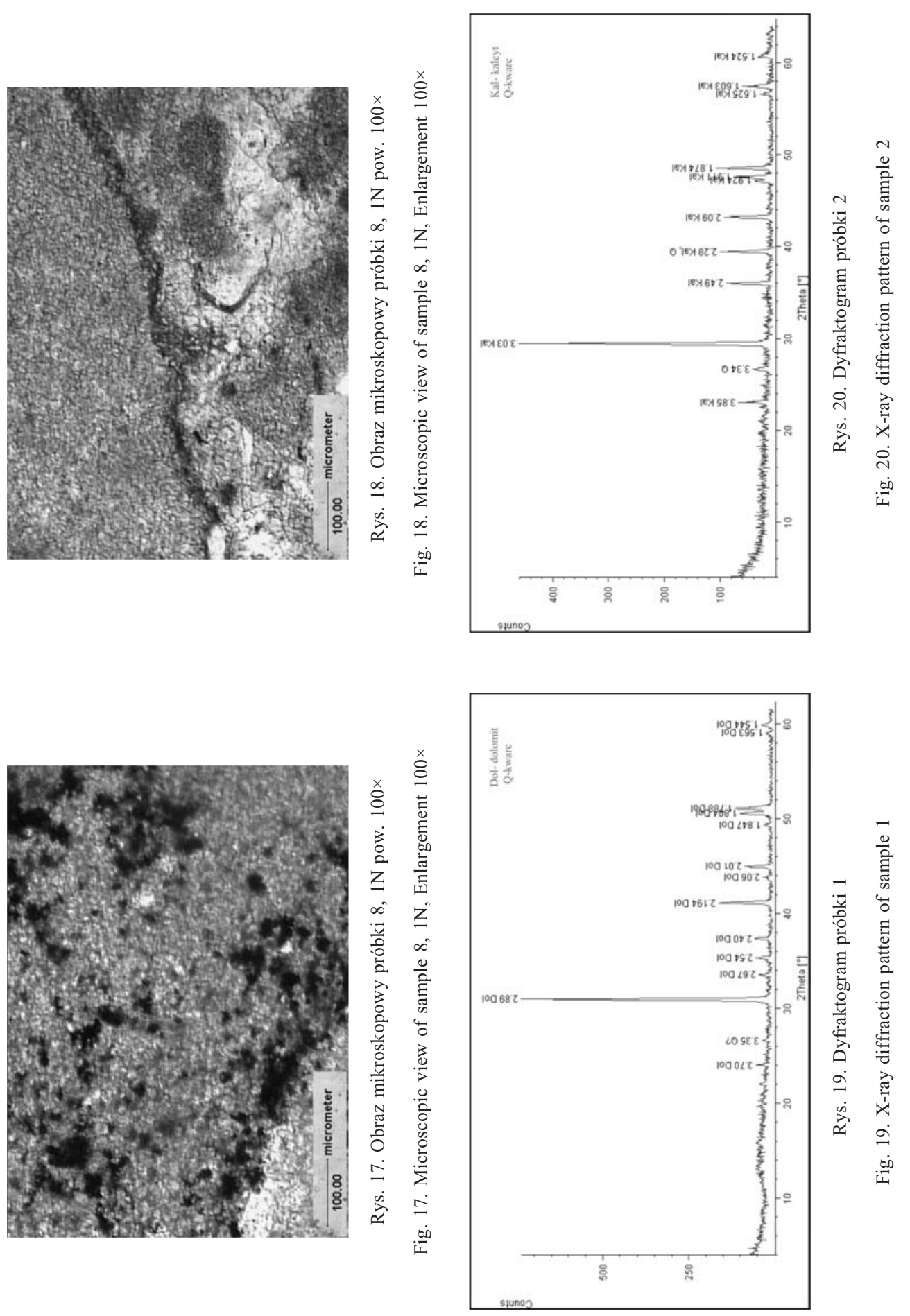

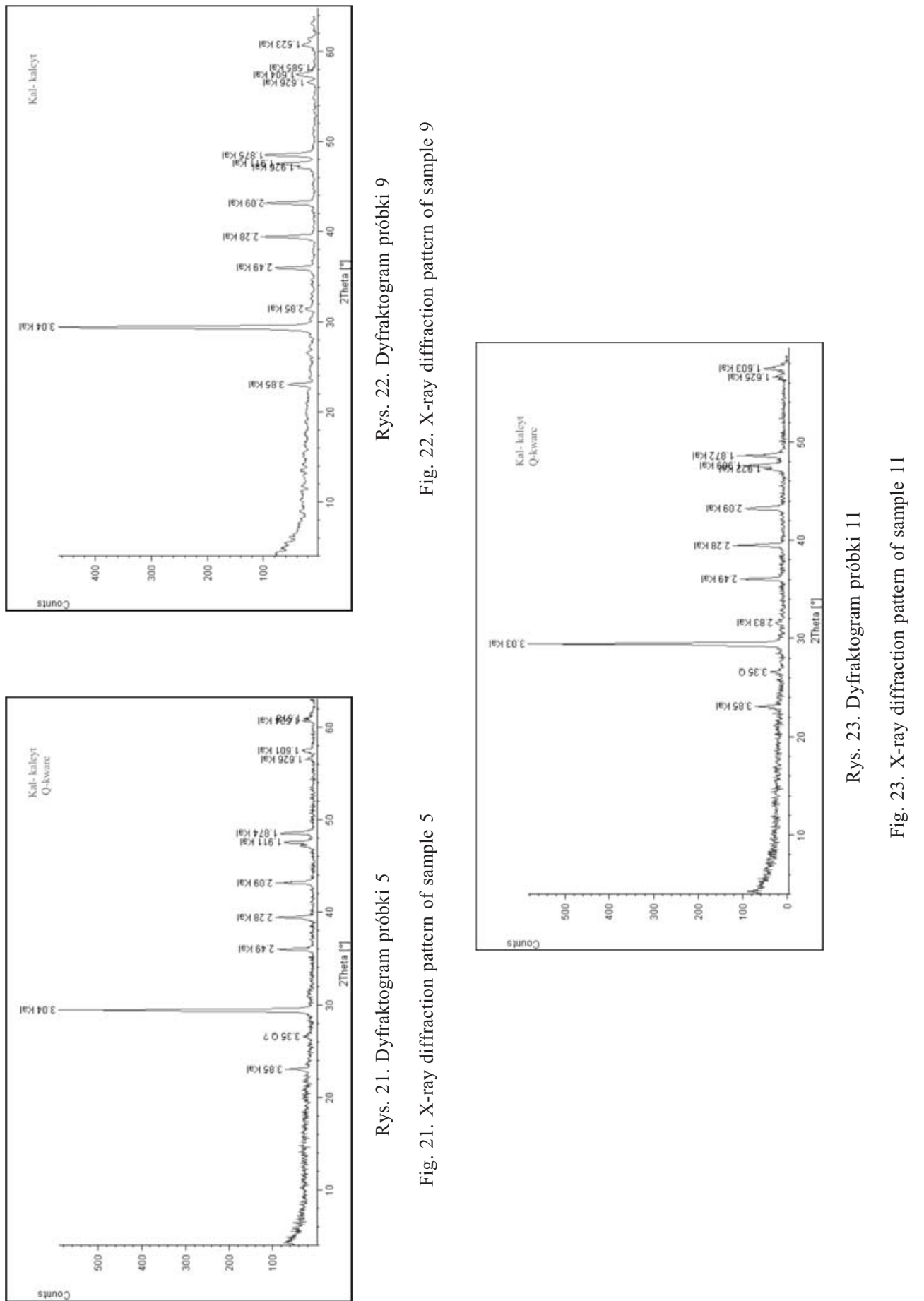
cementu w postaci sparytowych, romboedrycznych kryształów (rys. 15). W skałach obecne są również związki żelaza, występujące w postaci rozproszonej, miejscami tworzą agregaty lub wypełniają stylolity (rys. 17, 18).

Wyniki analizy makroskopowej oraz mikroskopowej wskazują, że próbki 2, 3, 4, 6, $7,8,9,10,11$ to wapienie, natomiast próbka 5 reprezentuje zlepieniec o zbudowanych z okruchów skał węglanowych, scementowanych spoiwem węglanowym.

\subsection{Wyniki analizy rentgenograficznej}

Wyniki analizy rentgenograficznej wskazują, że w przypadku większości badanych próbek, dominującą fazą węglanową jest kalcyt (rys. 20-22). Potwierdza to obecność szeregu linii dyfrakcyjnych typowych dla tej fazy. Wyjątek stanowi próbka 1 (rys. 19), w dyfraktogramie której ujawniły się linie dyfrakcyjne, o wysokich intensywnościach, pochodzące od dolomitu. W dyfraktogramach większości próbek $(1,2,5,11)$ (rys. 19, 20, 21, 23) stwierdzono także obecność linii dyfrakcyjnej 3,34 Å. Jest to najsilniejsza linia pochodząca od kwarcu. Jej mała intensywność wskazuje, że minerał ten występuje w podrzędnej ilości.

\subsection{Wyniki badań przy zastosowaniu elektronowego mikroskopu skaningowego}

Podczas badań, przy zastosowaniu elektronowego mikroskopu skaningowego, wykonano fotografie mikroobszarów analizowanych próbek, a także przeprowadzono mikroanalizę rentgenowską w mikroobszarach. W czasie wykonywania mikroanalizy ilościowej składu chemicznego, ze względu na napylenie próbek grafitem oraz ograniczenia metody EDS, węgiel i tlen oznaczone zostały jedynie jakościowo. Ilościowy udział $\mathrm{CO}_{2}$ obliczony został na podstawie zawartości $\mathrm{CaO}, \mathrm{MgO}$ i FeO.

Wyniki analizy, wykonane w wybranych punktach mikroobszarów badanych próbek (rys. 24 do 43) wykazały, że w badanych wapieniach dominuje węglanowa faza kalcytowa, z mniejszym udziałem faz zawierających magnez i żelazo oraz faz niewęglanowych, głównie krzemianowych i glinokrzemianowych. Wskazuje na to wysoka zawartość $\mathrm{CaO}$ (tab. 1 i 2 ) oraz obecność $\mathrm{w}$ widmach pierwiastkowych próbek węgla i tlenu. W wapieniu $\mathrm{z}$ utworów pstrego piaskowca stwierdzono niższą - w porównaniu z próbkami z warstw gogolińskich wapienia muszlowego - zawartość wapnia, a podwyższoną magnezu (tab. 1, rys. 24 do 27) co może świadczyć o dominacji w tej skale dolomitu oraz innych faz węglanowych, wzbogaconych w magnez (Davis, Dove, De Yoreo 2000; Deleuze, Brantley 1997). Niska zawartość krzemionki wskazuje na czystość faz węglanowych w tej skale. Skały utworów wapienia muszlowego (warstw gogolińskich) charakteryzują się zmienną, lecz wysoką zawartością $\mathrm{CaO}$ od 45,48 do 55,82\% (tab. 1 i 2), co potwierdza dominację kalcytu w tych wapieniach. Zawartość MgO jest tu zdecydowanie mniejsza, nie przekracza wartości 1\%, natomiast miejscami obserwuje się podwyższoną zawartość $\mathrm{SiO}_{2}$, przekraczającą w nie- 
82
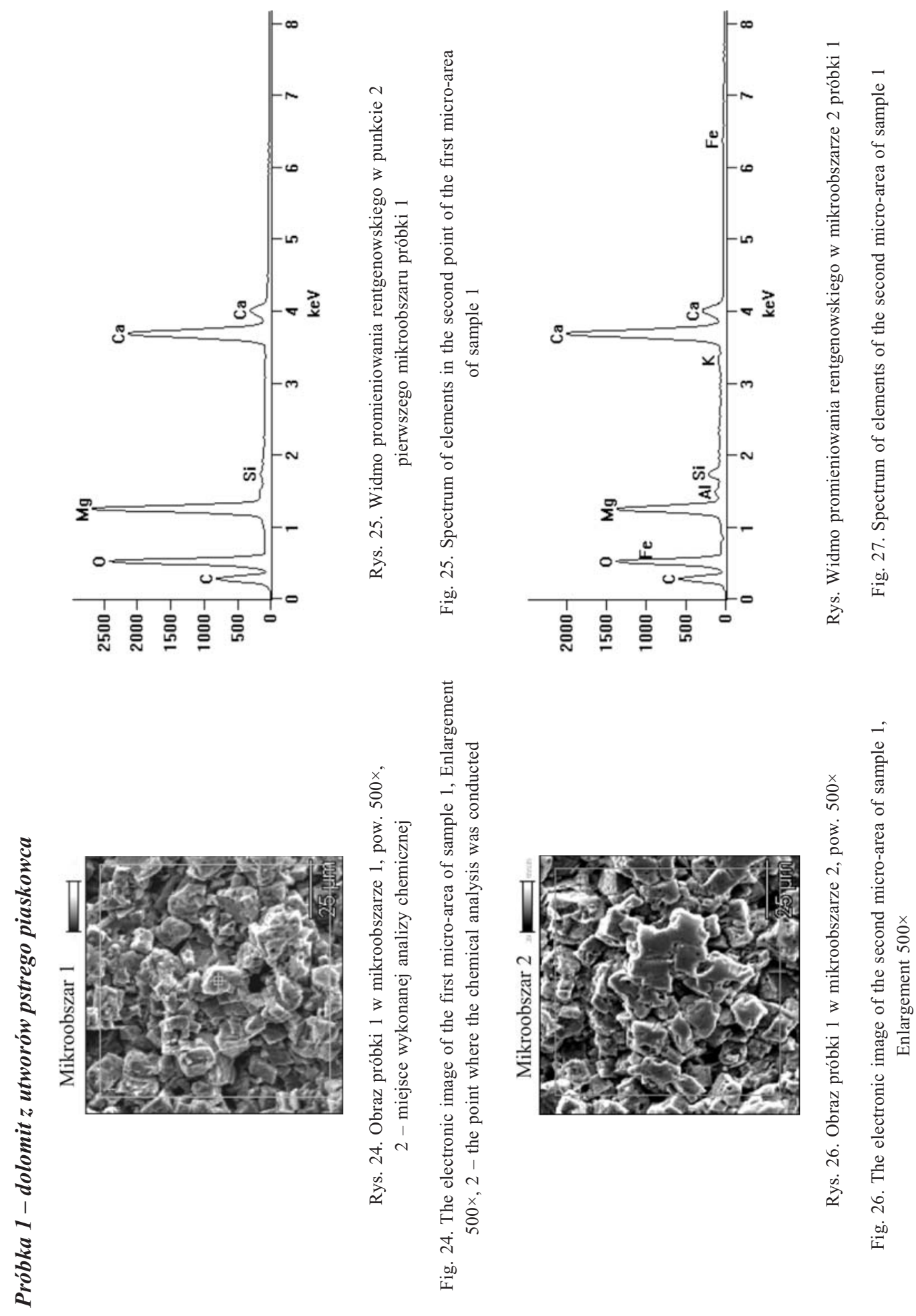

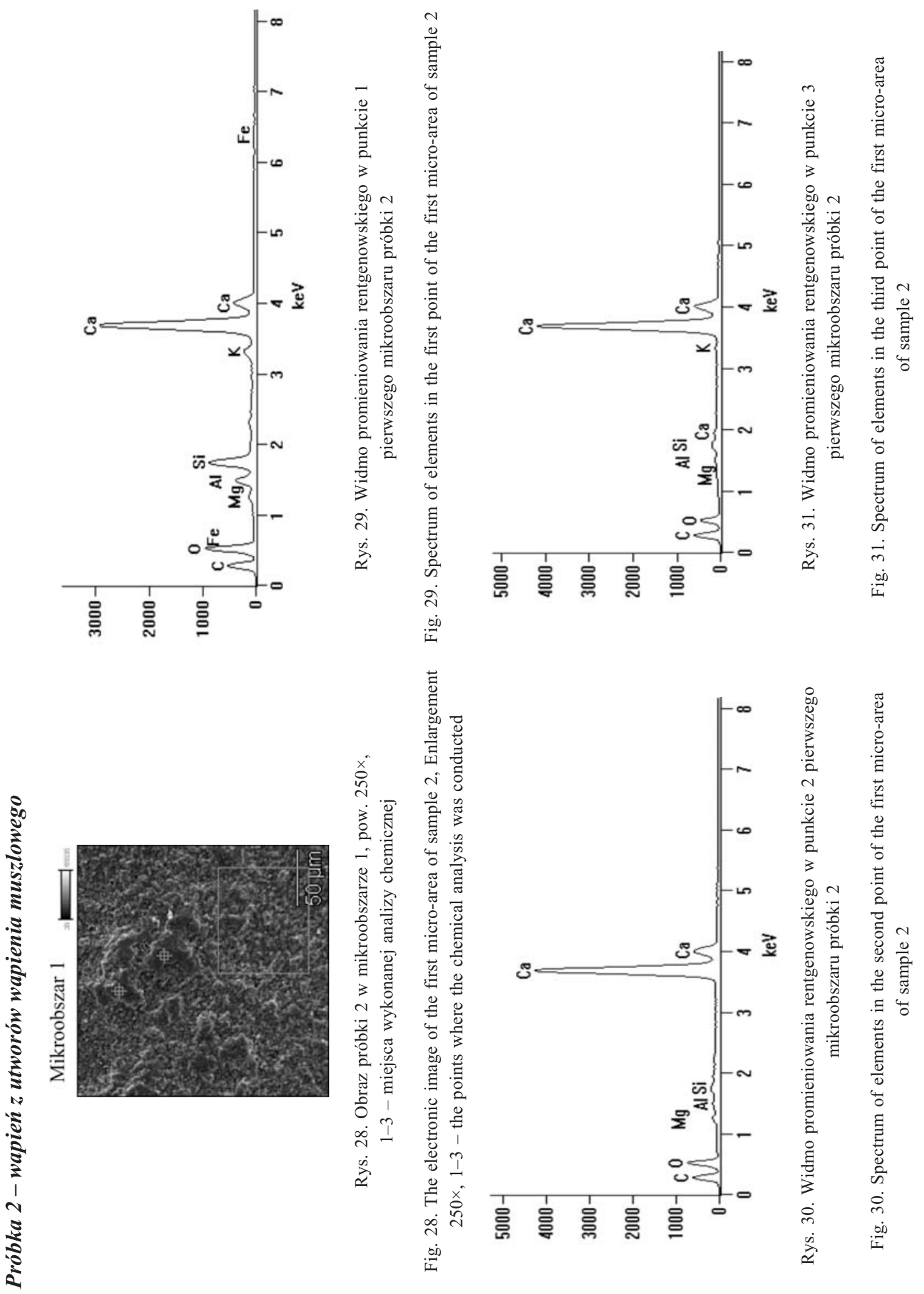

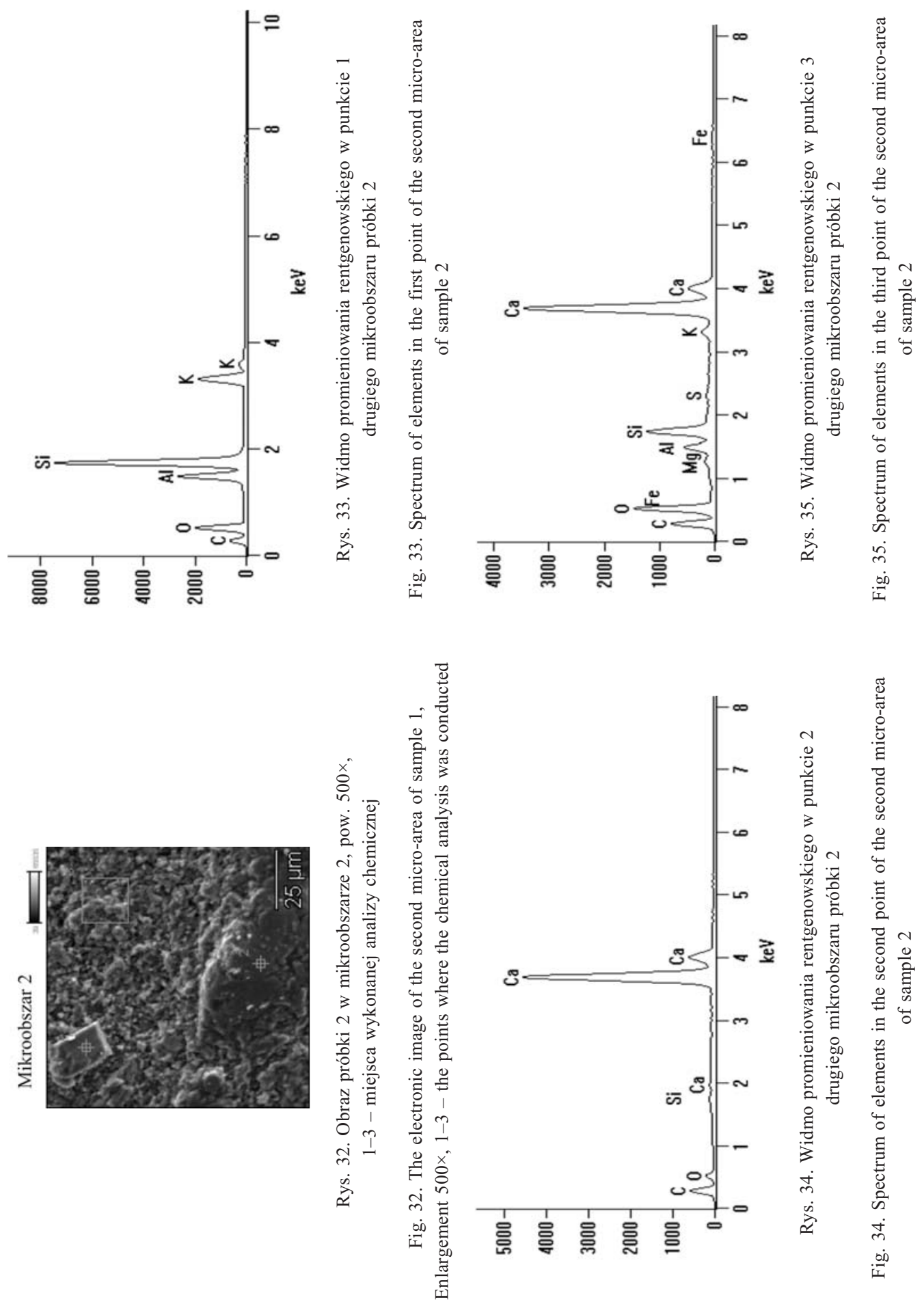
Ilościowy skład chemiczny w mikroobszarach próbek 1 i 2

The quantitative chemical composition in microareas of samples 1 and 2

\begin{tabular}{||c|c|c|c|c|c|c|c||}
\hline \multirow{2}{*}{$\begin{array}{c}\text { Składniki } \\
\text { chemiczne }\end{array}$} & \multicolumn{6}{|c|}{ Numery analizowanych chemicznie punktów w mikroobszarach próbek 1 i 2 [\%wag] } \\
\cline { 2 - 8 } & $\begin{array}{c}\text { Pr 1 } \\
\text { m1-pt 2 }\end{array}$ & $\begin{array}{c}\text { Pr 2 } \\
\text { m1-pt 1 }\end{array}$ & $\begin{array}{c}\text { Pr 2 } \\
\text { m1-pt 2 }\end{array}$ & $\begin{array}{c}\text { Pr 2 } \\
\text { m1-pt 3 }\end{array}$ & $\begin{array}{c}\text { Pr 2 } \\
\text { m2-pt 1 }\end{array}$ & $\begin{array}{c}\text { Pr 2 } \\
\text { m2-pt 2 }\end{array}$ & $\begin{array}{c}\text { Pr 2 } \\
\text { 22-pt 3 }\end{array}$ \\
\hline \hline $\mathrm{MgO}$ & 22,03 & 0,57 & 0,58 & 0,28 & 0,00 & 0,00 & 0,58 \\
\hline $\mathrm{SiO}_{2}$ & 0,40 & 9,70 & 0,74 & 0,94 & 65,81 & 0,38 & 10,67 \\
\hline $\mathrm{CaO}$ & 29,98 & 45,48 & 54,78 & 54,92 & 0,00 & 55,82 & 45,14 \\
\hline $\mathrm{Al}_{2} \mathrm{O}_{3}$ & 0,00 & 2,94 & 0,28 & 0,24 & 16,25 & 0,00 & 3,58 \\
\hline $\mathrm{FeO}$ & 0,00 & 2,23 & 0,00 & 0,00 & 0,00 & 0,00 & 1,39 \\
\hline $\mathrm{K}_{2} \mathrm{O}$ & 0,00 & 1,40 & 0,00 & 0,21 & 17,94 & 0,00 & 1,21 \\
\hline $\mathrm{SO}_{3}$ & 0,00 & 0,00 & 0,00 & 0,00 & 0,00 & 0,00 & 0,50 \\
\hline $\mathrm{CO}_{2}{ }^{*}$ & 47,59 & 37,68 & 43,62 & 43,41 & - & 43,81 & 36,91 \\
\hline
\end{tabular}

m2 - mikroobszar drugi, pt 2 - punkt 2

* Obliczona na podstawie zawartości $\mathrm{CaO}, \mathrm{MgO}$ i $\mathrm{FeO}$

TABELA 2

Ilościowy skład chemiczny w mikroobszarach 1 i 2 próbki 5

TABLE 2

The quantitative chemical composition in microareas 1 and 2 of sample 5

\begin{tabular}{||c|c|c|c|c|c|c|c||}
\hline \multirow{2}{*}{$\begin{array}{c}\text { Składniki } \\
\text { chemiczne }\end{array}$} & \multicolumn{6}{|c|}{ Numery analizowanych chemicznie punktów w mikroobszarach 1 i 2 próbki 5 [\%wag] } \\
\cline { 2 - 8 } & $\begin{array}{c}\text { Pr 5 } \\
\text { m1-pt 1 }\end{array}$ & $\begin{array}{c}\text { Pr 5 } \\
\text { m1-pt 2 }\end{array}$ & $\begin{array}{c}\text { Pr 5 } \\
\text { m1-pt 3 }\end{array}$ & $\begin{array}{c}\text { Pr 5 } \\
\text { m2-pt 1 }\end{array}$ & $\begin{array}{c}\text { Pr 5 } \\
\text { m2-pt 2 }\end{array}$ & $\begin{array}{c}\text { Pr 5 } \\
\text { m2-pt 3 }\end{array}$ & $\begin{array}{c}\text { Pr 5 } \\
\text { 2-pt 3 }\end{array}$ \\
\hline \hline $\mathrm{MgO}$ & 0,65 & 0,54 & 0,53 & 0,58 & 0,51 & 0,35 & 0,22 \\
\hline $\mathrm{SiO}_{2}$ & 3,48 & 0,68 & 5,35 & 3,42 & 9,30 & 0,72 & 0,34 \\
\hline $\mathrm{CaO}$ & 52,32 & 54,91 & 50,62 & 51,87 & 48,40 & 55,21 & 55,58 \\
\hline $\mathrm{Al}_{2} \mathrm{O}_{3}$ & 1,23 & 0,19 & 1,20 & 1,11 & 2,70 & 0,00 & 0,00 \\
\hline $\mathrm{FeO}^{2}$ & 0,00 & 0,00 & 0,90 & 0,70 & 0,00 & 0,00 & 0,00 \\
\hline $\mathrm{K}_{2} \mathrm{O}$ & 0,57 & 0,00 & 0,31 & 0,33 & 0,53 & 0,00 & 0,00 \\
\hline $\mathrm{SO}_{3}$ & 0,00 & 0,00 & 0,24 & 0,19 & 0,00 & 0,00 & 0,00 \\
\hline $\mathrm{CO}_{2}{ }^{*}$ & 41,76 & 43,68 & 40,85 & 41,78 & 38,55 & 43,72 & 43,86 \\
\hline
\end{tabular}

m2 - mikroobszar drugi, pt 2 - punkt 2

* Obliczona na podstawie zawartości $\mathrm{CaO}, \mathrm{MgO}$ i FeO 

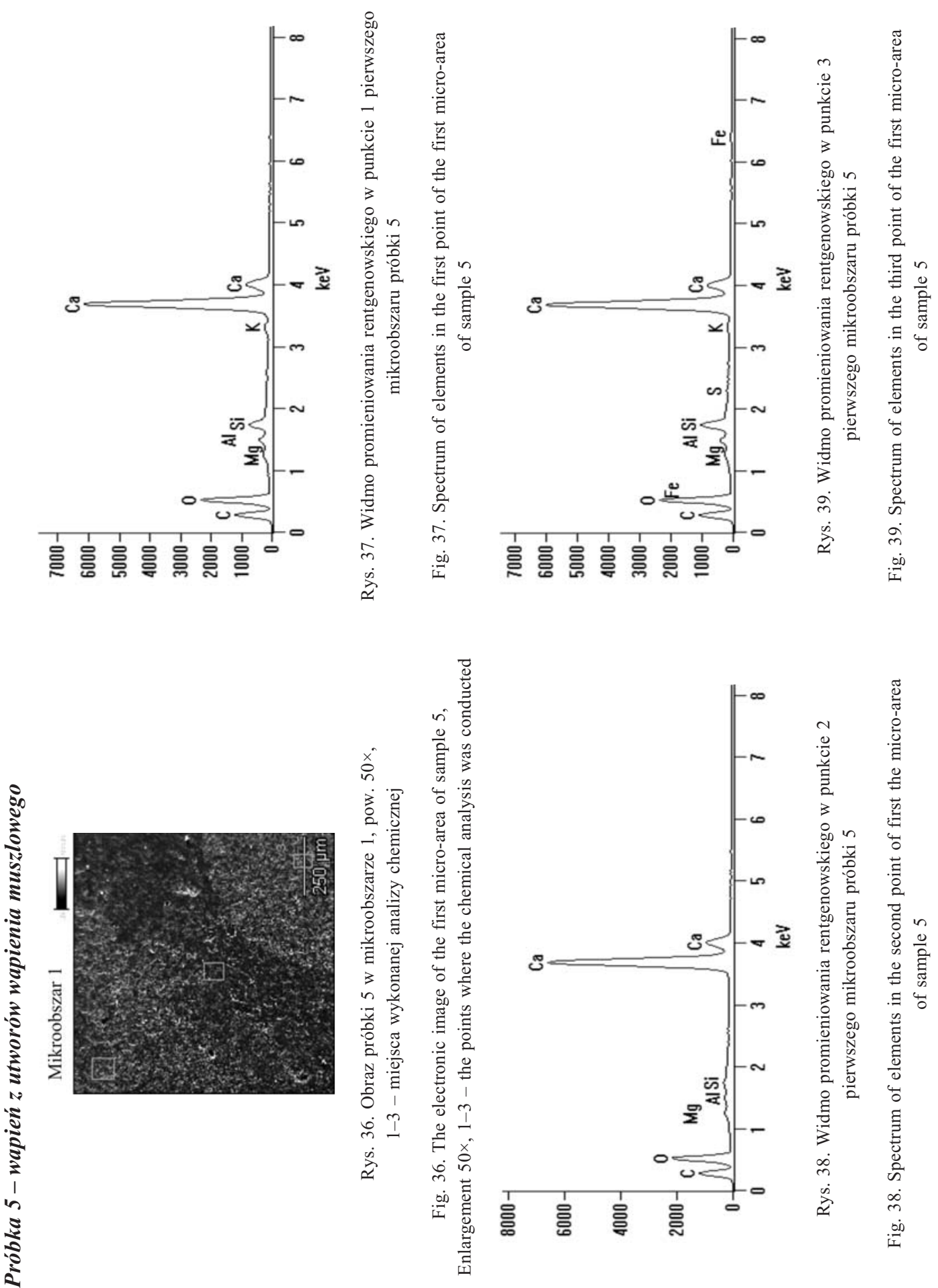

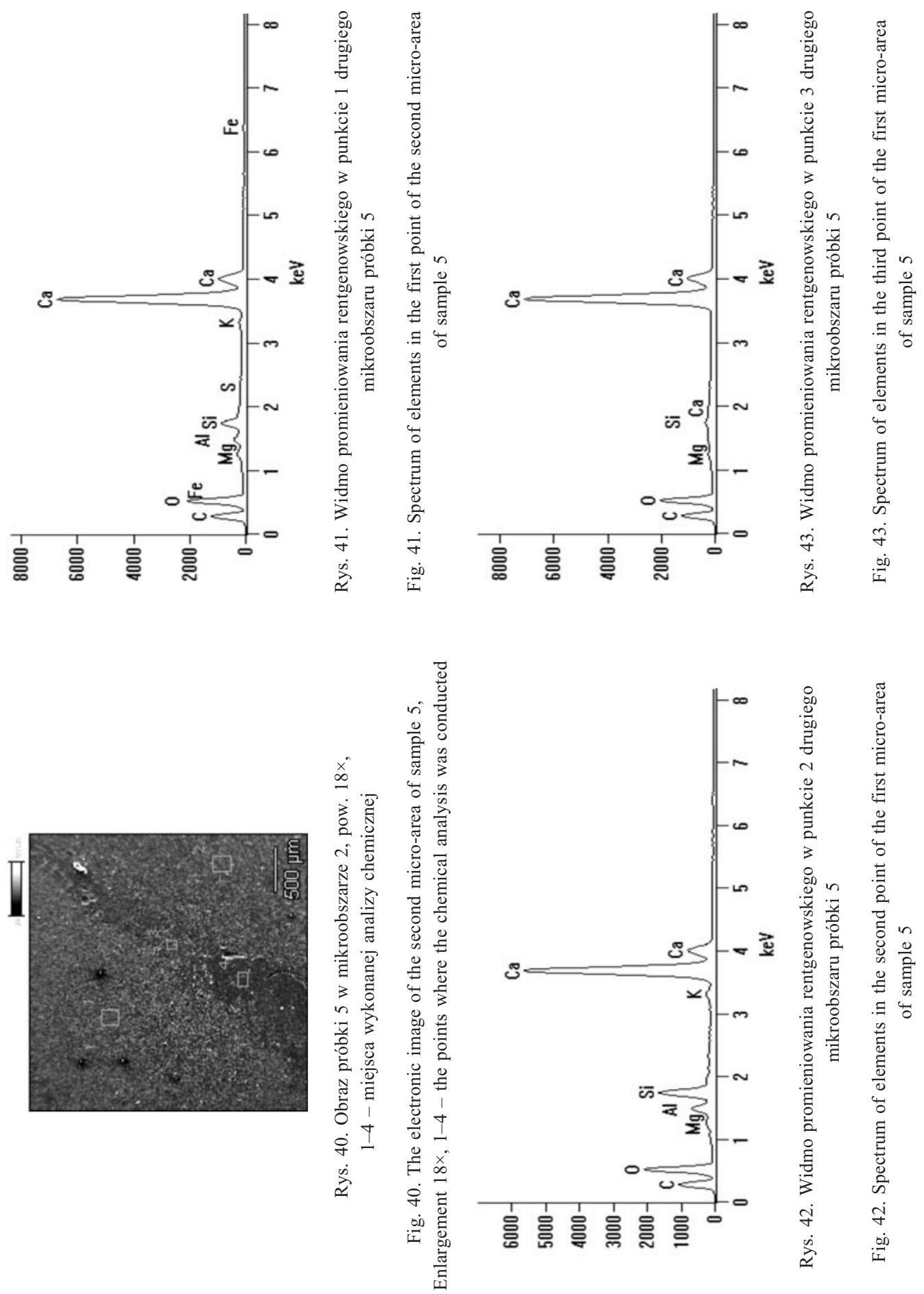
których punktach $9 \%$, a także $\mathrm{Al}_{2} \mathrm{O}_{3}$, o zawartości większej od 3\%. Podwyższone zawartości $\mathrm{SiO}_{2} \mathrm{i} \mathrm{Al}_{2} \mathrm{O}_{3}$ wskazują na obecność w skałach warstw gogolińskich domieszek faz krzemianowych i glinokrzemianowych (tab. 1 i 2). Potwierdza to również podwyższona ilość $\mathrm{K}_{2} \mathrm{O}$, w niektórych punktach przekraczająca wartość $1 \%$. Powyższe nie dotyczy jednak punktu 1 w mikroobszarze próbki 2, w którym zawartości $\mathrm{SiO}_{2}, \mathrm{Al}_{2} \mathrm{O}_{3}$ i $\mathrm{K}_{2} \mathrm{O}$ są zdecydowanie wyższe: $\mathrm{SiO}_{2}-65,81 \%, \mathrm{Al}_{2} \mathrm{O}_{3}-16,25 \%, \mathrm{~K}_{2} \mathrm{O}-19,94 \%$. Skład chemiczny, oznaczony w tym punkcie (pr. 2 m2-pt 1 - tab. 1, rys. 32) odpowiada teoretycznemu składowi skalenia potasowego.

Wzbogacenie w $\mathrm{SiO}_{2}, \mathrm{Al}_{2} \mathrm{O}_{3}$ i $\mathrm{K}_{2} \mathrm{O}$, może świadczyć o obecności w badanych skałach kwarcu, skaleni, mik oraz minerałów ilastych. Obecność siarki w analizowanych próbkach może wskazywać na podwyższone zasolenie wody morskiej zbiornika, w którym następowała sedymentacja wapieni, co potwierdza teorię o sedymentacji badanych skał w płytkim, epikontynentalnym zbiorniku morskim (Stanienda 2008; Szulc 1990, 2000).

\section{Wnioski}

Na podstawie uzyskanych wyników badań stwierdzono, że wśród skał pstrego piaskowca dominują dolomity, zbudowane głównie z masy sparytowej, zawierającej dolomit oraz w mniejszej ilości kalcyt. Kalcyt to głównie kryształy sparytowe, o zróżnicowanej wielkości. Prawdopodobnie jest to kalcyt drugiej generacji, który powstał w wyniku procesów zaawansowanej diagenezy, wskutek rekrystalizacji i agradacji ziaren utworzonych wcześniej. Dolomit występuje w postaci idiomorficznych, romboedrycznych kryształów. Tę fazę węglanową należałoby natomiast traktować jako produkt bezpośredniej krystalizacji lub wczesnodiagenetycznej dolomityzacji w luźnym, niezdiagenezowanym osadzie węglanu wapnia. W niewielkich ilościach występują również fazy niewęglanowe - kwarc, związki żelaza, minerały ilaste oraz muskowit, co potwierdzają wyniki analizy rentgenograficznej i badań w mikroobszarach.

Skały spągowej części utworów wapienia muszlowego (warstw gogolińskich) to głównie wapienie dwóch typów: odmiany zawierające allochemy i ortochemy oraz odmiany z mała ilością lub brakiem allochemów. Wyjątek stanowi próbka 5, która reprezentuje zlepieniec, zbudowany z okruchów skał węglanowych, spojonych cementem również węglanowym. Analizowane skały zbudowane są głównie z kalcytu. Ponadto, w analizowanych wapieniach stwierdzono również - jednak w mniejszej ilości - obecność faz niewęglanowych, takich jak: kwarc, muskowit oraz minerały ilaste. W skałach warstw gogolińskich można zaobserwować dwie generacje kalcytu. Kalcyt pierwszej generacji występuje w postaci ziaren mikrytowych, budujących niektóre szczątki organiczne. Minerał ten wchodzi też w skład spoiwa. Fazę tę należy traktować jako produkt bezpośredniej krystalizacji w luźnym osadzie węglanu wapnia. Kalcyt drugiej generacji - sparytowy, wypełniający niektóre allochemy, w tym trochity liliowców - powstał prawdopodobnie podczas procesów zaawansowanej diagenezy, wskutek rekrystalizacji i agradacji ziaren utworzonych wcześniej. Kryształy 
dolomitu, podobnie jak w skałach pstrego piaskowca, występują w spoiwie lub koncentrują się w obrębie masy sparytowej. Dolomit występuje w postaci idiomorficznych, romboedrycznych kryształów. Także tę fazę węglanową należałoby traktować jako produkt bezpośredniej krystalizacji lub wczesnodiagenetycznej dolomityzacji w luźnym, niezdiagenezowanym osadzie węglanu wapnia. Wyniki analizy w mikroobszarach przy zastosowaniu mikroskopu skaningowego wykazały, że w badanych skałach dominuje faza kalcytowa, z mniejszym udziałem faz zawierających magnez czy żelazo. Wyjątek stanowi próbka 1 (dolomit z utworów Pstrego Piaskowca), w której oznaczono podwyższoną zawartość magnezu wskazującą na obecność dolomitu. Wyniki analizy w mikroobszarach wykazały również, że badane wapienie oprócz zmiennej zawartości $\mathrm{MgO}$ są również zróżnicowane pod względem zawartości udziały $\mathrm{SiO}_{2}, \mathrm{Al}_{2} \mathrm{O}_{3}$ i $\mathrm{K}_{2} \mathrm{O}$, co wskazuje na obecność faz krzemianowych (kwarc) i glinokrzemianowych (skaleń potasowy, minerały ilaste, muskowit).

\section{LITERATURA}

B od zi o ch A., 1990 - International workshop field seminar the Muschelkalk- sedimentary environment, facies and diagenesis. Kraków-Opole, s. 9-11.

B o d zi o c h A., 1998 - Materiały XXXII Sympozjum Speleologicznego. Kamień Śląski, 23-25.10.1998 r., s. 6-7.

Davis K.J., Dove P.M., De Y or e o J.J., 2000 - The role of $\mathrm{Mg}^{2+}$ as an impurity in calcite growth. Science, vol. 290 .

Deleuze M., Brantley S.L., 1997 - Inhibition of calcite crystal growth by $\mathrm{Mg}^{2+}$ at $100^{\circ} \mathrm{C}$ and 100 bars: Influence of growth regime. Geochim. et Cosmochim. Acta, vol. 61, s. 1475-1485.

Encyklopedia Chorzowa. Praca zbiorowa pod red. G. Grzegorka. Prasa i Książka, Katowice 2009.

N ow a k J., 2007 - Obiekty geoturystyczne Chorzowa. Zeszyty Naukowe Politechniki Śląskiej, seria: Górnictwo, z. 280 , Gliwice.

Stanienda K., 2008 - Charakterystyka faz węglanowych w wapieniach triasowych warstw gogolińskich i górażdżańskich z Ligoty Dolnej, Góry Św. Anny i Gogolina. Zeszyty Naukowe Politechniki Śląskiej, seria: Górnictwo, z. 285, s. 259-269.

S t a n i enda K., 2011 - Przejawy dolomityzacji w wapieniach triasowych złoża „Tarnów Opolski”. Monografia, Wydawnictwo Politechniki Śląskiej, Gliwice.

Szulc J., 1990 - International Workshop - Field Seminar The Muschelkalk - Sedimentary Environments, Facies and Diagenesis - Excursion Guidebook and Abstracts. Kraków-Opole, s. 1-32.

Szulc J., 2000 - Middle Triassic evolution of the Northern Peri-Tethys area is influenced by early opening of the Tethys Ocean. Annales Societatis Geologorum Poloniae, vol. 70, s. 1-48.

W y c zółk ow s ki J., 1957 - Szczegółowa Mapa Geologiczna Polski Arkusz Zabrze.

„Ziemia” Dwutygodnik Krajoznawczy Ilustrowany Organ Polskiego Towarzystwa Krajoznawczego, rok XIII, nr 15-16, Warszawa, sierpień 1928, s. 240. 


\section{FAZY MINERALNE W TRIASOWYCH SKALACH WĘGLANOWYCH REJONU CHORZOWA}

\section{Słowa kluczowe}

Chorzów, pstry piaskowiec, wapień muszlowy, warstwy gogolińskie, skały węglanowe, wapienie, dolomity

\section{Streszczenie}

W niniejszym artykule przedstawiono wyniki badań próbek skał węglanowych pobranych z utworów triasowych w rejonie północnej części Chorzowa. Przedmiotem badań była identyfikacja faz mineralnych, obecnych w tych skałach, szczególnie faz węglanowych.

W północnej części Chorzowa występują utwory triasowe reprezentowane przez skały stropowej części profilu pstrego piaskowca oraz spągowej części profilu utworów wapienia muszlowego - warstw gogolińskich. Utwory te eksploatowane były w XIX i pierwszej połowie XX wieku.

W artykule przedstawiono wyniki analiz próbek skał węglanowych, pobranych z tych warstw. Wykonano ich opis petrograficzny, badania mikroskopowe w świetle przechodzącym, analizy dyfraktometryczne oraz badania składu chemicznego w mikroobszarach z wykorzystaniem mikroskopu skaningowego.

Na podstawie przeprowadzonych analiz stwierdzono, że w utworach pstrego piaskowca dominują dolomity. W składzie mineralnym tych skał, poza dolomitem, stwierdzono obecność sparytowego kalcytu, ponadto zidentyfikowano również kwarc, minerały ilaste, muskowit oraz związki żelaza.

Utwory wapienia muszlowego to głównie wapienie, a także zlepieńce otoczaków wapiennych scementowane spoiwem węglanowym. W składzie mineralnym tych skał dominuje kalcyt dwóch generacji. Kalcyt pierwszej generacji tworzy ziarna mikrytowe, natomiast kalcyt drugiej generacji występuje w postaci ziaren sparytowych, zróżnicowanych pod względem wielkości i kształtu. Miejscami w ziarnach sparytowych można zaobserwować doskonałą łupliwość romboedryczną. Ponadto w skałach zidentyfikowano również dolomit, a z minerałów niewęglanowych - kwarc, muskowit oraz minerały ilaste. Badania mikroskopowe wykazały zróżnicowanie struktur próbek wapieni od biomorficznej, przez organodetrytyczną, sparytową, mikrosparytową do mikrytowej.

MINERAL PHASES OF CARBONATE TRIASSIC ROCKS OF THE CHORZÓW AREA

$$
\text { Key words }
$$

Chorzów, Bundsandstein, Muschelkalk, Gogolin Beds, carbonate rocks, limestone, dolomite

\section{Abstract}

This article presents the results of research on carbonate rock samples taken from Triassic sediments of the northern area of Chorzów City. The aim of the research was to identify the mineral phases of these rocks, especially carbonate phases.

The rocks from the roof part of the Bundsandstein profile and floor part of the Muschelkalk profile - Gogolin Beds - are typical sediments from the northern part of Chorzów City. These rocks were mined in the XIX century and the beginning of the XX century.

The article also presents the results of research on samples of carbonate rocks taken from investigated strata. It provides a Petrographic description, the results of microscopic analysis executed in polarized, transmitted light, X-ray analysis, and microprobe measurements using a scanning microscope.

The results of these analyses showed that dolomites dominate in the Bunsandstein strata. Dolomites (The sampled rocks?) are composed mainly of dolomite, but sparry calcite was also identified. Moreover, quartz, clay minerals, muscovite and iron minerals were observed in the Bundsandstein rocks. The Muschelkalk sediments 
are mainly represented by limestone. In some areas, conglomerates were also found. The conglomerates are composed of carbonate rock boulders connected by carbonate cement. Two generations of calcite were observed while investigating the limestone. The first generation calcite is micritic, and the second generation calcite forms sparry crystals different in size and shape. In some areas of the sparry calcite it is possible to observe perfect rhobohedral cleavage. Moreover, dolomite, rhodohrosite, and noncarbonate minerals like quartz, muscovite, and clay minerals were identified. The results of microscopic analysis also showed that the limestone is different in texture. The limestone presents the following textures: biomorphic, detrical, sparry, microsparry and micritic. 
